\title{
The Relation between Tympanostomy Tube Otorrhea and Types of Immune Cells in Middle Ear Effusion in Children with Otitis Media with Effusion
}

\author{
Gil Chai Lim ${ }^{1}$, Chang Lim Hyun ${ }^{2}$, Dong Young Kim ${ }^{1}$, Seung Hyo Choi ${ }^{1}$, and Chan Il Song ${ }^{1}$ \\ ${ }^{1}$ Departments of Otolaryngology-Head and Neck Surgery, ${ }^{2}$ Pathology, Jeju National University School of Medicine, Jeju, Korea
}

\section{삼출성 중이염으로 환기관삽입술을 받은 소아에서 중이삼출액 내의 면역세포 유형과 환기관 이루 발생의 관계}

임길채 ${ }^{1} \cdot$ 현창림 $^{2} \cdot$ 김동영 $^{1} \cdot$ 최승효 ${ }^{1} \cdot$ 송찬일 $^{1}$

제주대학교 의학전문대학원 이비인후-두경부외과학교실, ${ }^{1}$ 병리학교실 ${ }^{2}$

\footnotetext{
Received April 14, 2017

Revised July 13, 2017

Accepted July 13, 2017

Address for correspondence

Chan Il Song, MD

Department of Otolaryngology-

Head and Neck Surgery,

Jeju National University

School of Medicine,

15 Aran 13-gil, Jeju 63241, Korea

Tel $+82-64-717-2108$

Fax $+82-64-757-8276$

E-mail songchanil@gmail.com
}

Background and Objectives Tympanostomy tube insertion is one of the most common surgical procedures in children. Despite aseptic procedures with prophylactic antibiotic treatment, postoperative otorrhea may be encountered in some patients. The purpose of this study is to identify the relation between the types of immune cells in otitis media with effusion (OME) and tympanostomy tube otorrhea (TTO) in children.

Subjects and Method Fifty-six patients underwent tympanostomy tube insertion with OME were analyzed retrospectively. Fluid from OME was harvested by suction via syringe connector after myringotomy. Light microscopic examination of middle ear effusion was performed by a pathologist after hematoxylin and eosin staining. We analyzed the relation between the types of immune cells from middle ear effusion and TTO.

Results Of 56 children, 36 were male and 22 were female. The mean age for tympanostomy tube insertion was $3.56( \pm 2.63)$ years, with the average follow-up period of $12.56( \pm 9.96)$ months. Neutrophils were detected in 19 , eosinophils in 14 , lymphocytes in 22 , mast cells in 2 , plasma cells in 7, and histiocytes in 9 . TTO occurred in 15 patients. In patients with early TTO, eosinophils were detected more frequently than in patients without TTO $(p=0.006)$. Plasma cells were detected more frequently in patient with late TTO than without TTO $(p=0.011)$.

Conclusion According to the analysis of different types of immune cells, eosinophils in the middle ear effusion related with the occurrence of TTO.

Korean J Otorhinolaryngol-Head Neck Surg 2018;61(3):133-8

Key Words Bacterial culture $\cdot$ Eosinophilic otitis media $\cdot$ Immune cells ·

Otitis media with effusion · Tympanostomy tube otorrhea.

\section{서 론}

소아에서 중이 환기관삽입술은 이비인후과에서 가장 많이

This is an Open Access article distributed under the terms of the Creative Commons Attribution Non-Commercial License (http://creativecommons.org/licenses/by-nc/4.0) which permits unrestricted non-commercial use, distribution, and reproduction in any medium, provided the original work is properly cited.
시행하는 수술 중 하나이며, 미국에서는 3세 이하의 소아에서 15 명 당 1 명 꼴로 수술이 시행될 정도로 흔하다. ${ }^{1)}$ 환기관삽 입술의 적응증은 지속되는 삼출성 중이염, 반복적인 중이염 또는 경구 항생제에도 반응하지 않는 중이 감염 등이다. ${ }^{2}$ 적 절하게 환기관삽입 수술을 시행하면, 청력이 개선되며 고막삼 출액도 줄어들고 반복적인 이루에서도 효과를 보일 수 있어, 
삶의 질 향상에 도움을 준다. ${ }^{3)}$ 그러나 환기관삽입 후에 이루 가 지속될 수 있으며, 환기관을 가지고 있는 동안 귀에 물이 들어가서 오염되거나 급성 중이염이 병발하는 경우 또는 악 안면기형이나 다운증후군, 알레르기, 유전적 소인이나 다양 한 환경적 요인들에 의해서도 환기관 이루(tympanostomy tube otorrhea)가 발생할 수 있다. ${ }^{4.5)}$ 환기관 이루는 환기관삽 입 후 가장 많이 나타나는 합병증이다. 기존의 보고에 따르 면 $16 \%$ 소아에서 수술 후 4주 이내 이루가 발생했고, 환기관 을 가지고 있는 전체 기간 중 최소 1 회 이상 이루를 경험한 환 아는 $26 \%$ 였으며 $7 \%$ 는 반복적인 환기관 이루를 경험하였다. ${ }^{5)}$ 환기관 이루의 치료는 경구 광범위 항생제나 국소적인 항생제 점이액을 이용하는 경우가 많으며, 치료에 반응을 하지 않는 경우에 중이 환기관을 제거하기도 한다.) 환기관 이루에 대한 적절한 치료에도 불구하고 이루가 지속되는 경우 호산구성 중 이염도 의심해 볼 수 있다.

본 연구에서는 환기관삽입술을 시행할 때 얻어진 중이삼 출액의 면역세포 유형을 분석하여 환기관 이루 발생 여부와 의 연관성을 분석하고, 이를 바탕으로 중이삼출액의 면역세 포 유형 분석이 환기관삽입술 후 이루 발생 여부를 예측하는 인자로서의 가능성을 알아보고자 하였다.

\section{대상 및 방법}

\section{대 상}

2012년 1월부터 2013년 7월까지 중이 환기관삽입술을 시행 한 만 12 세 이하의 환자 112 명 가운데 중이삼출액의 면역세포 유형을 분석한 환자 56명을 대상으로 연구를 진행하였다. 삼 출성 중이염으로 진단되고 최소 3 개월 이상의 경과관찰 기 간 중에 호전이 없었거나 3 개월 이내라도 고막의 구조가 변 화하거나 순음청력검사에서 역치가 평균 $40 \mathrm{~dB}$ 이상인 경우 의 환자를 대상으로 환기관삽입술을 시행하였다. 두개안면기 형이나 구개열, 전반적인 발달 장애 등이 있는 환아들은 연 구대상에서 제외하였다. 모든 환자들이 수술 전날 입원하였 고 입원했을 때부터 수술 직전까지 상기도 감염 증상이 있거 나 상기도 감염이 의심되는 경우에도 본 연구에서 제외하였 다. 중이 환기관삽입술을 시행한 후 모든 환아에게 7일간 경 구 항생제를 처방하였다. 수술 시 중이삼출액이 맑고 점도가 낮은 장액성 삼출액인 경우 경구 스테로이드를 처방하지 않았 으나 장액성 삼출액이 아닌 경우 경구 스테로이드를 12 일간 처 방하였다. 환아의 몸무게가 $20 \mathrm{~kg}$ 미만일 경우 methylprednisolone $1 \mathrm{mg}, 20 \mathrm{~kg}$ 이상 $40 \mathrm{~kg}$ 미만일 경우 methylprednisolone $2 \mathrm{mg}$ 을 사용하였다.

이 연구는 제주대학교병원 Institutional Review Board(IRB)
의 승인하에 진행되었다(IRB No. 2017-05-001).

\section{중이삼출액의 면역세포 유형 분석}

고막 절개술을 시행한 후 $5 \mathrm{~mL}$ 주사기에 $18 \mathrm{G}$ 척추천자침 (spinal needle)을 연결하여 중이삼출액을 흡인하였으며 이를 고정하여 hematoxylin \& eosin 염색을 시행하였다. 병리과 전 문의가 광학 현미경을 이용하여 호중구(neutrophil)와 호산구 (eosinophil), 호염구(basophil), 림프구(lymphocyte), 단핵구 (monocyte), 조직구(histiocyte), 형질세포(plasma cell), 비만 세포(mast cell) 등의 분포를 관찰하였다. 면역세포 수는 400 배의 광학 현미경 시야에서 10개의 고배율 시야(high-power field)를 관찰한 평균값으로 many(25개 초과), some(11 25 개), a few(3 10개), few(3개 미만), no(0개)의 5단계로 분류하 여 a few 이상으로 분류된 검체들만 유의한 자료로 포함하 여 분석하였다. 환기관 이루는 발생 시기에 따라 환기관삽입 술 후 2주 이내 발생하면 조기(early), 환기관삽입 2주 이후에 발생하면 후기(late)로 나누었으며, 8주 이상 이루가 지속될 때 만성(chronic), 2 회 이상의 이루가 발생하였으며 이루 발생 간에 3개월 이상의 시간 차이가 있을 경우 재발성(recurrent)으 로 정의하였다.

\section{통계 처리}

통계는 PASW statistics 18(SPSS Inc., Chicago, IL, USA) 을 이용하였으며, 두 군 간의 비교는 Fisher's exact test 방법 을 이용하였고, 통계적 유의 수준은 $p<0.05$ 인 경우를 유의 한 것으로 판정하였다.

\section{결 과}

총 56 명 중 남아는 35 명, 여아는 21명이었으며 평균 연령은 $3.56( \pm 2.63)$ 세였다. 환기관삽입술 시행 전 평균 경과관찰 기간 은 5.73( \pm 3.01$)$ 개월이며 환기관삽입술 시행 후 평균 경과관찰 기간은 $12.56( \pm 9.96)$ 개월이었다. 56 명의 환자에서 검출한 삼 출액을 분석했을 때 확인된 면역세포의 종류는 각각 호중구

Table 1. Types of immune cells from middle ear effusion

\begin{tabular}{lc}
\hline \multicolumn{1}{c}{ Types of immune cells } & No. of patients $(\mathrm{n}=56)$ \\
\hline Neutrophils & 19 \\
Eosinophils & 14 \\
Basophils & 0 \\
Lymphocytes & 22 \\
Monocytes & 0 \\
Histiocytes & 9 \\
Plasma cells & 7 \\
Mast cells & 2 \\
\hline
\end{tabular}


(19명), 호산구(14명), 림프구(22명), 조직구(9명), 형질세포(7 명), 비만세포(2명)였고 호염기구와 단핵구와 유의한 수 이상 으로 확인된 환자는 없었다(Table 1).

경과관찰 기간 중 15 명(26.8\%)에서 환기관 이루가 있었고, 발 생한 시기에 따라 조기에 발생한 군이 9명, 후기에 발생한 군 이 6명, 만성인 군이 5명, 재발성인 군이 3명이었다. 이들 환자 에서 검출된 면역세포의 종류는 각각 호중구(8명, 53.3\%), 호 산구(7명, 46.7\%), 림프구(5명, 33.3\%), 형질세포(5명, 33.3\%), 조직구(2명, $13.3 \%)$ 였다. 환기관 이루가 발생한 환자군과 환기
관 이루가 발생하지 않은 환자군으로 나누어 양군에서 삼출 액 내의 면역세포 분포를 비교하였을 때 통계적으로 유의한 차이를 보인 면역세포는 호산구 $(p=0.037)$ 와 형질세포 $(p=0.012)$ 였다(Table 2). 이들 중 조기에 환기관 이루가 발생한 9명에서 삼출액 내의 면역세포 분포를 보면, 호중구(5명, 55.6\%), 호산 구(6명, 66.7\%), 림프구(3명, 33.3\%), 형질세포(2명, 22.2\%), 조직 구(1명, $11.1 \%)$ 였다. 조기에 환기관 이루가 발생한 환자군과 환기관 이루가 발생하지 않은 환자군에서 삼출액 내의 면역 세포 분포를 비교하였을 때 통계적으로 유의한 차이를 보인

Table 2. Comparison of types of immune cells between with TTO and without TTO

\begin{tabular}{lccc}
\multicolumn{1}{c}{ Types of immune cells } & No. of patients with TTO $(n=15)$ & No. of patients without TTO $(n=41)$ & p value \\
\hline Neutrophils (\%) & $8(53.3)$ & $11(26.8)$ & 0.109 \\
Eosinophils (\%) & $7(46.7)$ & $7(17.1)$ & 0.037 \\
Lymphocytes (\%) & $5(33.3)$ & $17(41.5)$ & 0.759 \\
Histiocytes (\%) & $2(13.3)$ & $7(17.1)$ & 1.000 \\
Plasma cells (\%) & $5(33.3)$ & $2(4.9)$ & 0.012 \\
Mast cells (\%) & $0(0.0)$ & $2(4.9)$ & 1.000 \\
\hline
\end{tabular}

TTO: tympanostomy tube otorrhea

Table 3. Comparison of types of immune cells between with early TTO and without TTO

\begin{tabular}{lccc}
\hline \multicolumn{1}{c}{ Types of immune cells } & No. of patients with early TTO $(n=9)$ & No. of patients without TTO $(n=41)$ & $p$ value \\
\hline Neutrophils (\%) & $5(55.6)$ & $11(26.8)$ & 0.124 \\
Eosinophils (\%) & $6(66.7)$ & $7(17.1)$ & 0.006 \\
Lymphocytes (\%) & $3(33.3)$ & $17(41.5)$ & 0.724 \\
Histiocytes (\%) & $1(11.1)$ & $7(17.1)$ & 1.000 \\
Plasma cells (\%) & $2(22.2)$ & $2(4.9)$ & 0.144 \\
Mast cells (\%) & $0(0.0)$ & $2(4.9)$ & 1.000 \\
\hline
\end{tabular}

TTO: tympanostomy tube otorrhea

Table 4. Comparison of types of immune cells between with late TTO and without TTO

\begin{tabular}{lcrc}
\hline \multicolumn{1}{c}{ Types of immune cells } & No. of patients with late TTO $(\mathrm{n}=6)$ & No. of patients without TTO $(\mathrm{n}=41)$ & $\mathrm{p}$ value \\
\hline Neutrophils (\%) & $3(50)$ & $11(26.8)$ & 0.344 \\
Eosinophils (\%) & $1(16.7)$ & $7(17.1)$ & 1.000 \\
Lymphocytes (\%) & $2(33.3)$ & $17(41.5)$ & 1.000 \\
Histiocytes (\%) & $1(16.7)$ & $7(17.1)$ & 1.000 \\
Plasma cells (\%) & $3(50.0)$ & $2(4.9)$ & 0.011 \\
Mast cells (\%) & $0(0.0)$ & $2(4.9)$ & 1.000 \\
\hline
\end{tabular}

TTO: tympanostomy tube otorrhea

Table 5. Comparison of types of immune cells between with early TTO and with late TTO

\begin{tabular}{lccc}
\hline \multicolumn{1}{c}{ Types of immune cells } & No. of patients with early TTO $(\mathrm{n}=9)$ & No. of patients with late TTO $(\mathrm{n}=6)$ & $\mathrm{p}$ value \\
\hline Neutrophils (\%) & $5(55.6)$ & $3(50.0)$ & 1.000 \\
Eosinophils (\%) & $6(66.7)$ & $1(16.7)$ & 0.119 \\
Lymphocytes (\%) & $3(33.3)$ & $2(33.3)$ & 1.000 \\
Histiocytes (\%) & $1(11.1)$ & $1(16.7)$ & 1.000 \\
Plasma cells (\%) & $2(22.2)$ & $3(50.0)$ & 0.329 \\
Mast cells (\%) & $0(0.0)$ & $0(0.0)$ & - \\
\hline
\end{tabular}

TTO: tympanostomy tube otorrhea 
면역세포는 호산구( $p=0.006)$ 였다(Table 3$)$. 후기에 환기관 이 루가 발생한 환자군과 환기관 이루가 발생하지 않은 환자군 에서 삼출액 내의 면역세포 분포를 비교하였을 때는 형질세 포 $(p=0.011)$ 가 통계적으로 유의한 차이를 보였다(Table 4). 조기에 환기관 이루가 발생한 환자군과 후기에 환기관 이루 가 발생한 환자군에서 삼출액 내의 면역세포 분포를 비교하 였을 때는 통계적으로 유의한 차이를 보이는 면역세포는 없 었다(Table 5).

환기관 이루가 발생한 경우 세균배양검사를 시행하였으며, 3명에서 Candida albicans 가 배양되었고, Streptococcus pneumoniae 가 1명에서 배양되었다(Table 6).

삼출액의 면역세포 유형분석을 시행한 56 명의 환자 중 중 이삼출액이 장액성이 아니었던 48명에서 환기관삽입술 후 경 구 스테로이드를 처방하였다. 경구 스테로이드를 복용한 48 명의 환자 중 수술 후 12 일간의 경구 스테로이드 복용 이후에 국소 스테로이드 점이액을 추가로 처방받은 환자는 4명이었으 며, ofloxacin 점이액을 처방받은 환자는 20명이었다.

경구 스테로이드를 처방하지 않은 8명의 환자 중에서 추가 로 국소 스테로이드 이용액을 처방받은 환자는 없었으며 ofloxacin 점이액을 처방받은 환자는 2 명이었다. 경구 스테로 이드를 복용한 환자군에서 환기관 이루가 발생한 경우가 12 명 (25\%)이었고 경구 스테로이드를 복용하지 않은 환자군에서는 3 명(37.5\%)에서 환기관 이루가 발생하였으며, 두 군 간의 통계 적으로 유의한 차이는 없었다.

환기관 이루가 발생한 15 명의 환자에게는 경구 항생제와 ofloxacin 점이액 처방을 포함하여 추가적인 치료를 하였으며, 적절한 약물 치료에도 불구하고 이루가 지속되거나 반복되어
환기관을 제거한 경우는 2 명이었다.

수술 직전 시행한 혈액검사에서 호산구가 전체 백혈구의 $5 \%$ 이상으로 상승된 소견을 보였던 환자는 3 명이었으나 이들은 모두 환기관 이루가 없었고 삼출액을 분석했을 때 호산구가 확인된 경우는 없었다.

\section{고 찰}

대부분의 삼출성 중이염에서 중이 점막의 염증화 과정이 선 행된다. 이관 기능 저하, 구개열, 아데노이드 증식증 등에 의해 서도 삼출성 중이염이 발생할 수 있지만 박테리아, 바이러스, 알레르기 반응에 의한 중이 점막의 염증으로 인해 분비된 싸 이토카인이 만성 삼출성 중이염에서 중요한 역할을 한다.7) 그 중 면역 조절 싸이토카인인 interleukin(IL)-2, IL-10, transforming growth factor $-\beta$ 가 급성 염증기에서 만성 염증기로 의 이행에 중요한 역할을 하며, IL-4, IL-5와 granulocyte macrophage colony-stimulating factor는 체액성 면역과 알레르 기성 염증 과정에서 면역글로불린 생산과 분비를 조절하여 만성 삼출성 중이염을 일으킨다고 알려져 있다. ${ }^{89)}$ 이러한 싸 이토카인의 변화는 중이삼출액의 면역세포 조성에도 변화를 일으킬 것으로 가정하였으며 이를 분석하여 삼출성 중이염 의 예후와의 연관성을 알아보고자 하였다.

본 연구에서 환기관 이루가 발생한 환자들 중에서 일부는 수술 후 2주 이상 시간이 지난 후에 이루가 발생하였으며 이러 한 경우 삼출성 중이염과 직접적으로 관련된 이루일 가능성 보다는 오염에 의한 감염일 가능성이 높을 것으로 가정하였 다. 조기에 환기관 이루가 발생한 환자들에서 통계적으로 유

Table 6. Laboratory results of patients with tympanostomy tube otorrhea

\begin{tabular}{|c|c|c|c|c|c|c|c|c|}
\hline No. & Neutrophils & Lymphocytes & Eosinophils & Plasma cells & Histiocytes & Onset of TTO & Frequency of TTO & Culture \\
\hline 1 & & & + & + & + & Late & Recurrent & No growth \\
\hline 2 & & + & & + & + & Early & Recurrent & No growth \\
\hline 3 & + & & & + & & Late & Once & Candida albicans \\
\hline $4^{*}$ & & & + & + & & Early & Chronic & No growth \\
\hline 5 & & + & & & & Late & Once & No growth \\
\hline $6^{*}$ & + & + & + & & & Early & Chronic & Candida albicans \\
\hline 7 & & & & & & Late & Once & No growth \\
\hline $8^{*}$ & + & & + & & & Early & Chronic & S. pneumoniae \\
\hline 9* & + & & + & & & Early & Chronic & No growth \\
\hline 10 & & & & & & Early & Once & No growth \\
\hline 11 & + & & & & & Late & Once & No growth \\
\hline 12 & + & + & + & & & Early & Chronic & No growth \\
\hline 13 & + & + & & & & Late & Recurrent & Candida albicans \\
\hline 14 & + & & + & & & Early & Once & No growth \\
\hline 15 & & & & & & Early & Once & No growth \\
\hline
\end{tabular}

*patients who were sustected eosinophilic otitis media. TTO: tympanostomy tube otorrhea, S. pneumoniae: Streptococcus pneumoniae 
Table 7. Diagnostic criteria of eosinophilic otitis media

Major

OME or COM with eosinophilic dominant effusion Minor

1. Highly viscous middle ear effusion

2. Resistance to conventional treatment for otitis media

3. Association with bronchial asthma

4. Association with nasal polyposis

Definitive case

Positive for major+two or more minor criteria

Exclusion criteria

Churg-Straus syndrome, hypereosinophilic syndrome

OME: otitis media with effusion, COM: chronic otitis media

의하게 호산구의 발견 비율이 높은 것으로 나타났으며 후기 에 이루가 발생한 환자군과 구분되는 특징이라고 판단할 수 있었다.

조기에 환기관 이루가 발생하였으며 삼출액에서 호산구가 발견되는 경우 호산구성 중이염을 의심하고 다른 임상적 증 상의 동반 여부를 확인하는 것이 중요하다. 호산구성 중이염 (eosinophilic otitis media)은 대개 천식을 동반하면서 점성이 높은 이루와 호산구의 침윤으로 정의되는 질병으로 일반적 인 치료에 잘 반응하지 않아 만성적으로 점도가 높은 이루가 지속되는 양상을 보인다. 그 밖에도 알레르기성 비염, 만성 비 부동염, 비용종이 동반될 수 있다. ${ }^{10)}$ 본 연구에 포함된 환자 들의 의무기록 및 검사, 치료 결과를 후향적으로 분석하였을 때, 호산구성 중이염이 의심되는 환자는 총 4명이었다. Iino 등 ${ }^{11)}$ 이 2011년 발표한 호산구성 중이염의 진단기준(Table 7) 에 따라 진단하였다. 이들은 모두 중이삼출액에서 호산구가 관찰되었고, 점도 높은 이루를 보이고, 항생제 치료에 잘 반 응하지 않았으며 세균 배양 결과는 모두 음성이었다. 2명은 천 식으로 진단받았으며 나머지 2 명에서는 천식과 비용종 여부 에 대한 명확한 의무기록은 없었다. 이들은 수술 후 처방한 12 일간의 경구 스테로이드 복용 이후에, 추가적인 경구 스테 로이드와 국소 스테로이드 점이액 치료를 하였고 이루의 호전 을 보였다.

이전의 연구에서는 Streptococcus pneumoniae와 Moraxella catarrhalis가 삼출성 중이염 환아의 이루에서 가장 많이 발견되었다. ${ }^{12)}$ 그러나 최근 국내의 연구에서는 삼출성 중이염 과 관련된 병원균으로 Staphylococcus aureus, Fungus, Heamophilus influenzae의 순서로 빈도가 높음을 보고하였다. ${ }^{13)}$ 본 연구에서는 일부에서 Candida albicans와 Streptococcus pneumoniae가 배양되었으나 통계적인 의미를 분석하기에는 균배 양 검체 수가 적었고 삼출성 중이염과 직접적으로 관련된 감 염이라기보다는 중이 환기관삽입술 후 발생한 오염일 가능성 이 높은 것으로 판단하였다. 특히 Fungus는 이루의 일차적인 원인인 경우보다 이루가 발생한 상태에서 이차적으로 오염되
었을 가능성이 높다고 판단하고 있으며 경구 스테로이드 사용 과의 연관성도 낮다고 판단하고 있다. Candida albicans가 배 양된 3명 중 2명의 환아(Table 6: 3번, 13 번)들은 특별한 기저 질환이 없었고, 수술 2주 이상 지난 후에 이루가 발생하였기 때문이고, 호산구성 중이염이 의심되었던 1명의 환아(Table 6: 6번)는 지속적으로 경구 및 국소 스테로이드 치료를 지속하 면서 이루가 호전되었던 것으로 보아 스테로이드 사용에 의한 면역저하로 Candida albicans의 감염이 발생하였다고 보기 힘들기 때문이다. 환기관삽입술 후 발생하는 오염에 의한 균감 염을 제외하는 경우, pneumococcal 백신과 Heamophilus influenzae type B 백신 접종률이 증가함으로 인해 삼출성 중이 염과 관련된 병원균주의 변화가 있었을 가능성이 높다. ${ }^{14}$

수술 전 시행한 혈액검사에서 호산구가 전체 백혈구의 $5 \%$ 이상으로 상승된 소견을 보였던 환자들이 있었으나 이들은 모두 환기관 이루가 없었고 삼출액을 분석했을 때 호산구가 확인된 경우는 없었다. 반대로 삼출액 내의 면역세포 분석에 서 호산구가 발견되었던 환자들 중 수술 전 혈액검사에서 호 산구가 상승된 소견을 보인 경우 역시 없었다. 통계적인 분석 을 위한 수로는 부족하지만 본 연구의 결과로 보아서는 혈액 내의 호산구 상승과 중이삼출액 내의 호산구 증가가 관련성 을 가졌을 가능성은 낮을 것으로 추정된다.

본 연구에서는 삼출액 내 면역세포의 유형을 분석하여 환 기관삽입술 이후 이루 발생에 대한 예후를 예측하고자 하였 다. 대부분의 면역세포의 경우 통계적으로 유의하지 않으나 호산구가 일정 수준 이상으로 관찰된 경우 환기관 이루가 발 생하는 빈도가 높은 것으로 관찰되었다. 그러나 전체 환자군 의 크기가 충분하지 않고 환기관삽입술 후 이루가 발생한 환 자의 수가 15 명으로, 이 연구만으로 통계학적인 유의성을 논 하기에는 미흡하다. 56명의 연구 대상자 중 48명에서 수술 후 경구 스테로이드를 복용하도록 하였는데 이는 통계적으로 유의한 차이를 보이지는 않은 것으로 분석되었으나, 수술 후 경구 스테로이드를 복용한 환자들과 복용하지 않은 환자들 의 환기관 이루 발생률에 영향을 주는 교란인자로 작용하였 을 가능성을 완전히 배제할 수 없다. 따라서 더 큰 환자군에 서 추가적인 연구를 통해 중이삼출액의 면역세포 분포와 환 기관 이루 발생과의 관련성에 대한 충분한 자료 수집이 필요 하겠다.

\section{REFERENCES}

1) Kogan MD, Overpeck MD, Hoffman HJ, Casselbrant ML. Factors associated with tympanostomy tube insertion among preschoolaged children in the United States. Am J Public Health 2000;90(2): 245-50

2) Browning GG, Rovers MM, Williamson I, Lous J, Burton MJ. Grommets (ventilation tubes) for hearing loss associated with otitis 
media with effusion in children. Cochrane Database Syst Rev 2010; (10):CD001801.

3) Rosenfeld RM, Bhaya MH, Bower CM, Brookhouser PE, Casselbrant ML, Chan KH, et al. Impact of tympanostomy tubes on child quality of life. Arch Otolaryngol Head Neck Surg 2000;126(5):585-92.

4) Cheng J, Javia L. Methicillin-resistant Staphylococcus aureus (MRSA) pediatric tympanostomy tube otorrhea. Int J Pediatr Otorhinolaryngol 2012;76(12):1795-8.

5) Rosenfeld RM, Schwartz SR, Pynnonen MA, Tunkel DE, Hussey HM, Fichera JS, et al. Clinical practice guideline: Tympanostomy tubes in children. Otolaryngol Head Neck Surg 2013;149(1 Suppl):S1-35.

6) Granath A, Rynnel-Dagöö B, Backheden M, Lindberg K. Tube associated otorrhea in children with recurrent acute otitis media; results of a prospective randomized study on bacteriology and topical treatment with or without systemic antibiotics. Int J Pediatr Otorhinolaryngol 2008;72(8):1225-33.

7) Smirnova MG, Birchall JP, Pearson JP. The immunoregulatory and allergy-associated cytokines in the aetiology of the otitis media with effusion. Mediators Inflamm 2004;13(2):75-88.

8) Bernstein JM, Park BH. Defective immunoregulation in children with chronic otitis media with effusion. Otolaryngol Head Neck Surg 1986;
94(3):334-9.

9) Yellon RF, Leonard G, Marucha PT, Craven R, Carpenter RJ, Lehmann $\mathrm{WB}$, et al. Characterization of cytokines present in middle ear effusions. Laryngoscope 1991;101(2):165-9.

10) Kanazawa H, Yoshida N, Iino Y. New insights into eosinophilic otitis media. Curr Allergy Asthma Rep 2015;15(12):76.

11) Iino $Y$, Tomioka-Matsutani $S$, Matsubara $A$, Nakagawa $T$, Nonaka $M$. Diagnostic criteria of eosinophilic otitis media, a newly recognized middle ear disease. Auris Nasus Larynx 2011;38(4):456-61.

12) Buzatto GP, Tamashiro E, Proenca-Modena JL, Saturno TH, Prates MC, Gagliardi TB, et al. The pathogens profile in children with otitis media with effusion and adenoid hypertrophy. PLoS One 2017;12(2): e0171049.

13) Kim H, Choo OS, Jang JH, Park HY, Choung YH. Chronological changes in microbial profiles in external and middle ear diseases: a 20-year study in Korea. Eur Arch Otorhinolaryngol 2017;274(3): 1375-81.

14) van Dongen TM, Venekamp RP, Wensing AM, Bogaert D, Sanders EA, Schilder AG. Acute otorrhea in children with tympanostomy tubes: prevalence of bacteria and viruses in the post-pneumococcal conjugate vaccine era. Pediatr Infect Dis J 2015;34(4):355-60 